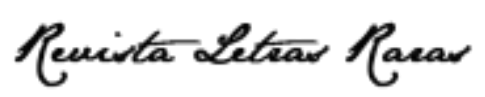

ISSN: 2317-2347 - v. 10, n. 3 (2021)

Todo o conteúdo da RLR está licenciado sob Creative Commons Atribuição 4.0 Internacional

\title{
Entre a razão e a paixão: o mito ovidiano de Píramo e Tisbe
}

\author{
revisitado em Romeu e Julieta, de Shakespeare / \\ Between reason and passion: the Ovidian myth of Pyramus and \\ Thisbe revisited in Shakespeare's Romeo and Juliet
}

Jorge Alves Pinto *

Possui graduação em Letras - Língua Inglesa pela Universidade Federal de Campina Grande (2020) e atualmente é aluno especial do mestrado em Literatura na Universidade Federal da Paraíba. Áreas de interesse: Literaturas de Língua Inglesa, particularmente narrativas escritas no século XIX, narrativas homoeróticas e Estudos Literários.

(iD) https://orcid.org/0000-0003-0869-0934

\section{Viviane Moraes de Caldas ${ }^{* *}$}

Professora Adjunta de Latim, na Universidade Federal de Campina Grande, Paraíba. Doutora em Letras pela Universidade Federal da Paraíba (UFPB). Pesquisadora Visitante, no Instituto de Filologia Clássica da Universidade de Viena (Áustria, 2017). Mestre em Letras (Linguagem e Ensino) pela Universidade Federal de Campina Grande (UFCG).

(iD) https://orcid.org/0000-0002-8898-2568

Recebido em: 23 abr. 2021. Aprovado em: 05 jun. 2021.

\section{Como citar este artigo:}

PINTO, Jorge Alves; DE CALDAS, Viviane Moraes. Entre a razão e a paixão: o mito ovidiano de Píramo e Tisbe revisitado em Romeu e Julieta, de Shakespeare. Revista Letras Raras. Campina Grande, v. 10, n. 3, p. 162 - 185, set. 2021.

\section{RESUMO}

O presente artigo tem como objetivo realizar uma análise de duas obras literárias: Romeu e Julieta, de William Shakespeare e o mito Píramo e Tisbe, presente no livro IV das Metamorfoses, do poeta latino Ovídio. Ao comparar os dois textos, investigamos seus aspectos trágicos à luz do Estoicismo, como proposto pelo filósofo e tragediógrafo latino Sêneca. Os principais aportes teóricos são os textos de Sêneca, Cícero e Brun (1986) para as discussões acerca do

$\triangle \quad$ alvesjorge11119@gmail.com

**

vivianemoraes@gmx.de

http://dx.doi.org/10.35572/rlr.v10i3.2141 


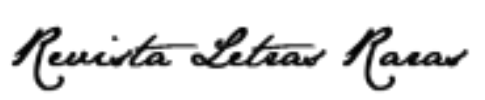

ISSN: 2317-2347 - v. 10, n. 3 (2021)

Todo o conteúdo da RLR está licenciado sob Creative Commons Atribuição 4.0 Internacional

Estoicismo; Aristóteles, Ubersfeld (2010) e Brait (1980) para as considerações acerca da personagem e do trágico; Bate e Rasmussen (2007) e Heliodora (2016) para discussões sobre Shakespeare; Closel (2011), Lucas (1922), e Lohner e Freitas (2014) para orientar as considerações acerca da influência latina no teatro Elisabetano. Consideramos que as personagens responsáveis por moverem os enredos nas duas obras deixam-se influenciar pelo affectus e, tomados pela paixão, contrária à razão, tomam decisões imprudentes que resultam em catástrofes. As catástrofes semelhantes em Shakespeare e em Ovídio retratam as consequências da alma que permite que a paixão se instale, colocando de lado a sua racionalidade. A morte trágica, como resultado do não comedimento, funciona, no trágico, como um recurso pedagógico aos leitores dos textos trágicos em questão.

PALAVRAS-CHAVE: Píramo e Tisbe; Romeu e Julieta; Estoicismo senequiano;Affectus; Tragédia.

\section{ABSTRACT}

This work aims to analyze two literary works: Romeo and Juliet by William Shakespeare and the myth of Pyramus and Thisbe, present in Book IV of The Metamorphoses, by the Latin poet Ovid. Comparing both, we investigate their tragic aspects in the light of Stoicism, according to the Latin philosopher and tragedian Seneca. The theoretical background includes Seneca, Cicero, and Brun (1986) for discussions regarding Stoicism; Aristotle, Brait (1980), and Ubersfeld (2010) for remarks concerning the character and the tragic; Bate and Rasmussen (2007) and Heliodora (2016) for discussions on Shakespeare; Closel (2011), Lucas (1922), and Lohner and Freitas (2014) to guide considerations about the Latin influence in the Elizabethan theatre. We believe that the characters responsible for moving the plots in the two works allow themselves to be influenced by affectusand, driven by passion, contrary to reason, they make imprudent decisions that result in catastrophes. Similar catastrophes in Shakespeare and Ovid portray the consequences of the soul that allows passion to settle, setting aside its rationality. As a result of non-restraint, tragic death functions as a pedagogical resource in the action for the readers of the tragic texts in question.

KEYWORDS: Pyramus and Thisbe; Romeo and Julie; The Stoicism of Seneca; Affectus; Tragedy.

\section{Introdução}

Muito provavelmente não podemos afirmar que As Metamorfoses, do poeta latino Ovídio, seja uma obra popular, isto é, que os não pesquisadores e estudantes de Letras Clássicas conseguiriam remeter de imediato de que se trata a obra. Acreditamos que ao resgatar elementos de sua composição e, portanto, propor investigações de seu texto, estamos cooperando com a difusão e atualização de seu vasto arcabouço narrativo e os temas que o compõe. William Shakespeare, por sua vez, parece ser mais popularmente difundido, posto que a adaptação de suas obras para 0 cinema e outras mídias favorece a permanência das temáticas universais das quais trata o bardo em suas produções literárias. Romeu e Julieta, a título de exemplo, uma de suas principais tragédias, permanece viva no imaginário comum de diversas formas: desde a leitura da peça no texto fonte até a combinação de uma sobremesa, qual seja queijo e goiabada.

Ainda que alguns não saibam quem foi Shakespeare, mas consigam identificar qualquer informação sobre Romeu e Julieta, isto prova a imortalidade do ator e dramaturgo inglês que, no 


\section{Penista Letear parar}

ISSN: 2317-2347 - v. 10, n. 3 (2021)

Todo o conteúdo da RLR está licenciado sob Creative Commons Atribuição 4.0 Internacional

final do século XVI e início do XVII, fez parte da consolidação do que hoje entendemos como Teatro Elisabetano. Embora o Teatro Elisabetano não contasse com Shakespeare como único dramaturgo, seu nome foi o mais notável, tanto pela forma como construía a ação dramática, como por ter integrado uma companhia diretamente ligada à corte, a saber, The Chamberlain's Man e, posteriormente quando o rei James I assumiu o trono em 1603, The King's Man.

Shakespeare teve contato com a literatura latina já que, não sendo de família tão pobre, frequentou a escola (grammarschool), onde estudou latim, e estudando os latinos - Ovídio, Virgílio e Horácio -, consequentemente teve acesso aos gregos através deles. Suas tragédias têm inspiração nos textos latinos em alguns aspectos formais e, em termos de enredo, Shakespeare os elaborava a partir de histórias que faziam parte da cultura popular medieval, tendo sido consagrado pela forma como tomou essas histórias e recontou-as à sua maneira. Portanto, é o modo como ele organiza e reconstrói as tramas, conferindo novos pontos de vista e temas, que the confere destaque e notoriedade (HELIODORA, 2016).

É válido destacar a influência em particular do filósofo e tragediógrafo Sêneca nas tragédias shakespearianas. As tragédias de Sêneca e Shakespeare apresentam semelhanças em sua construção dramática, inclusive vale ressaltar que, durante o século XVI, na Inglaterra, os textos latinos eram utilizados em aulas de latim e, posteriormente, foram traduzidos para a língua inglesa, portanto a tradição latina é perceptível nas tragédias da época, mesmo antes de Shakespeare. No que tange aos elementos do legado latino na composição dramática do poeta inglês, podemos destacar, de acordo com Luna (2008), a convenção linguística de adotar uma linguagem mais elevada, aspecto este que remonta à tradição, ao alto estilo e mesmo a elevação de status dos heróis trágicos, e também o emprego do terrível-ultrapatético senequiano, por meio da ênfase nos conflitos trágicos fechados:

O cuidado do poeta em "metamorfosear" o negativismo de seus conflitos trágicos cerrados com aparições finais de novos personagens sugestivos de esperança (Malcolm em Macbeth, Fortinbras em Hamlet e Richmond em Richard III), nem é regra em suas tragédias, nem se explica pela influência dessa tradição medieval, sendo talvez (...) um recurso inspirado em Ovídio (LUNA, 2008, p. 127). 


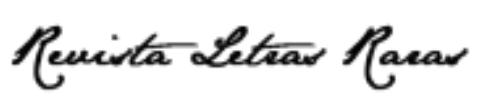

ISSN: 2317-2347 - v. 10, n. 3 (2021)

Todo o conteúdo da RLR está licenciado sob Creative Commons Atribuição 4.0 Internacional

O primeiro compilado de traduções de peças senequianas foi publicado em 1581 sob o título Seneca His Tenne Tragedies: Translated Into Englysh. Closel (2011), em seu estudo sobre a história da influência senequiana no teatro Elisabetano, discorre com base em Spearing (1912) e Winston (2006) que uma das motivações para a tradução das peças de Sêneca teria sido a popularização desses textos bem como a obtenção de privilégios políticos.

Frank Lawrence Lucas, em seu livro Seneca and the Elizabethan Tragedy, afirma que um dos motivos pelos quais os textos de Sêneca encenados na época foram bem recebidos está relacionado a uma semelhança cultural entre a Inglaterra Elisabetana e o Império Romano de Sêneca. Acerca da preferência pelos latinos em detrimento dos gregos, Lucas aponta que

esta preferência não era por acaso e não meramente porque o Latim era mais familiar que o Grego. A jovem ascensão do drama inglês não encontrou nada nos Clássicos tão próximos de seu nível quanto a senilidade declinante dos romanos. A Roma de Nero tinha a crueza do excesso, a Inglaterra Elisabetana a crueza da fome, a Roma daquele a crueldade sobre a sofisticação e decadência, a Inglaterra desta a crueldade da juventude crua e primitiva (LUCAS, 1922, p. $108)^{1}$.

O estudo de Lucas, bem como de outros que pesquisaram acerca do tema, não trazem tanta luz à questão filosófica das peças de Shakespeare quando postas lado a lado com as de Sêneca. Lucas (1922) realiza comparações para encontrar similaridades nos versos, ou outros elementos que fizessem parte do teatro de Sêneca, como a presença de fantasmas, a moralização, a estrutura em cinco atos, dentre outros:

Além do substrato estoico, dispositivos retóricos de que Sêneca lançou mão são localizados pelos pesquisadores principalmente na fase inicial de Shakespeare, nos dramas históricos, como Richard III. Ali, são patentes construções de diálogos de confrontação análogas às das peças de Sêneca. Mas em Hamlet encontram-se também traços do autor latino, como a self-dramatization nos solilóquios. Na fase final da carreira, em The Tempest há ainda indícios da elocução senequiana na invocação a divindades por Próspero (LOHNER; FREITAS, 2014, p.102).

\footnotetext{
1 "This preference was no mere chance, and not merely because Latin was more familiar than Greek. The rising infancy of English drama could find nothing in Classics so near its own level as the declining senility of Roman. Nero's Rome had the crudity of surfeit, Elizabethan England the crudity of hunger, his Rome the cruelty of over sophistication and decadence, her England the cruelty of raw and primitive youth" (LUCAS, 1922, p. 108). (Todas as traduções de Lucas (1922) são de nossa responsabilidade).

doi) http://dx.doi.org/10.35572/rlr.v10i3.2141
} 


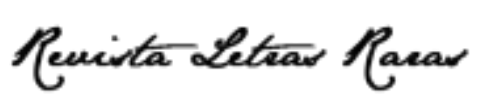

ISSN: 2317-2347 - v. 10, n. 3 (2021)

Todo o conteúdo da RLR está licenciado sob Creative Commons Atribuição 4.0 Internacional

Romeu e Julieta, uma de suas principais tragédias "se revela de modo particularmente [clara] no uso que ele fez de sua fonte virtualmente única, o poema The Tragicall Historye of Romeus and Juliet [de Arthur Brooke]" (HELIODORA, 2016, p. 8). Acreditamos, porém, que, embora Shakespeare tenha utilizado Brooke como fonte para composição de sua tragédia, ele tenha tomado também como referência o mito de Píramo e Tisbe, presente nas Metamorfoses de Ovídio. Podemos conjecturar ainda que o mito ovidiano pode ter servido de inspiração para Arthur Brooke. Sobre a influência latina em Shakespeare, Bate e Rasmussen apontam:

suspeita-se que sua mente consciente teria ficado mais envolvida com as histórias que encontrou: em Ovídio ele leu sobre obsessões eróticas e transformações mágicas do homem para besta, em César ele encontrou 0 vocabulário técnico para guerra, em Salústio as maquinações da conspiração e poder políticos (BATE; RASMUSSEN, 2007, p. 20)²

No presente artigo, procederemos a uma análise comparativa da narrativa mitológica ovidiana de Píramo e Tisbe e da tragédia shakespeariana Romeu e Julieta, com o objetivo de observar suas intersecções trágicas à luz do estoicismo de Sêneca, identificando a influência do tragediógrafo latino nos textos trágicos em questão. Os dois textos a serem analisados são ambos considerados por nós como ações trágicas, uma vez que no decorrer das ações "uma após outras sucedidas [se dá] o transe da infelicidade para a felicidade ou da felicidade à infelicidade" (Arist., Po. 1451a 15) $)^{3}$.

Podemos resumir os dois enredos do seguinte modo: Píramo e Tisbe são dois jovens de famílias distintas que, impedidos pelos pais de se encontrarem, conversam por meio de uma fresta na parede que separa suas casas, apaixonam-se e decidem fugir juntos. Combinam de se encontrarem próximo ao sepulcro de Nino, mas Tisbe chega antes de Píramo e é surpreendida por

\footnotetext{
2 "One suspects that his conscious mind would have been more engaged by the stories he encountered: in Ovid he read of erotic obsessions and magical transformations from man to beast, in Caesar he found the technical vocabulary of warfare, and in Sallust the machinations of conspiracy and power politics" (BATE; RASMUSSEN, 2007, p. 20). (Todas as traduções de Bate; Rasmussen (2007) são de nossa responsabilidade).

${ }^{3}$ As referências de autores antigos (gregos e latinos), no corpo do texto, não seguem as normas da ABNT; elas são feitas informando o autor, a obra e as divisões internas, que são usadas universalmente em boas edições. Essa forma é necessária de modo que se possa localizar o texto em qualquer edição.
}

doi http://dx.doi.org/10.35572/rlr.v10i3.2141 


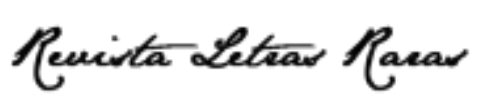

ISSN: 2317-2347 - v. 10, n. 3 (2021)

Todo o conteúdo da RLR está licenciado sob Creative Commons Atribuição 4.0 Internacional

uma leoa. Ao fugir do animal, deixa cair seu véu, que a leoa apanha em sua boca, que estava já suja de sangue. Quando Píramo chega ao lugar marcado e não vê sua amada, mas apenas o véu ensanguentado, desespera-se e apunhala a si mesmo com a adaga. Tisbe saindo do seu esconderijo encontra Píramo quase morto, toma-lhe nos braços e, vendo-o morrer, apunhala-se também a si mesma.

Romeu e Julieta são membros das famílias Montéquio ${ }^{4}$ e Capuleto, respectivamente. As duas famílias são conhecidas em Verona por serem rivais. Em um baile na casa dos Capuleto, Romeu encontra-se com Julieta pela primeira vez e eles se apaixonam. Após alguns encontros às escondidas, por pressão de Frei Lourenço, decidem se casar. Casam-se, mas não podem ficar juntos, pois Romeu intervira em um duelo entre Mercúcio e Teobaldo, matando este último. 0 resultado foi o exílio de Romeu. Julieta, prometida anteriormente ao Conde Páris, encontra junto a Frei Lourenço a solução de tomar uma espécie de antídoto que a fará parecer morta enquanto dorme. O Frei manda um recado para Romeu na cidade vizinha explicando o que combinara com Julieta. A mensagem, entretanto, não chega até Romeu porque o mensageiro fica "preso" em uma cidade por causa de uma quarentena. Um amigo de Romeu chega primeiro e conta que Julieta está morta. Ele vai para Verona e encontra Julieta no túmulo dos Capuleto. Pensando que Julieta está realmente morta, toma o veneno que adquirira de um boticário. Ela acorda logo depois e, vendo Romeu morto, toma sua adaga e apunhala-se no peito.

Um aspecto comum que permeia as duas narrativas, nosso objeto de estudo, é o páthos, ou seja, o sofrimento que acomete a alma do herói fazendo com que ele tome uma atitude movido pela falta de razão. Dentre os aspectos do estoicismo sobre os quais centraremos nossa análise, destacamos o affectus, movimento irracional da alma que, contrário à razão, subordina o sujeito a um estado sobre o qual ele não possui controle. Para Sêneca, a alma tomada pelo affectus está desprovida da razão e, portanto, do comedimento, estando sujeita aos vícios e cada vez mais distante da virtude. Perceberemos, ao analisar os textos de Shakespeare e de Ovídio, como se dá a ocorrência e influência do affectus, ou paixão, e suas eventuais consequências para as ações trágicas das personagens. Sêneca traz em sua obra (filosófica e trágica) os conceitos estoicos de

${ }_{4}^{4}$ Optamos pela grafia em língua portuguesa do nome Montéquio ao invés da grafia italiana Montecchio, uma vez que estamos utilizando a tradução brasileira de Bárbara Heliodora (2016) para o texto de Romeu e Julieta.

doil http://dx.doi.org/10.35572/rlr.v10i3.2141 


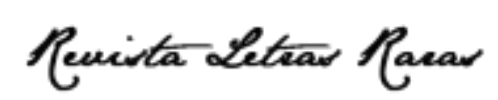

ISSN: 2317-2347 - v. 10, n. 3 (2021)

Todo o conteúdo da RLR está licenciado sob Creative Commons Atribuição 4.0 Internacional

modo que, por meio dela, os leitores possam aprender. Ou seja, o objetivo do filósofo e tragediógrafo é auxiliar o indivíduo a seguir o caminho da virtude. Dessa forma, os textos trágicos ora analisados podem ser considerados como pedagógicos, uma vez que ensinam os leitores que 0 affectus pode causar a sua ruína.

Utilizaremos como referencial teórico Bate e Rasmussen (2007) que tecem um estudo acerca das obras completas de Shakespeare; a Poética de Aristóteles (1993) e Luna (2005) para refletirmos acerca da estrutura da ação trágica. Para discutirmos acerca do affectus, as obras de Sêneca serão nosso guia, principalmente, os textos: Sobre a ira e as Cartas a Lucílio. Reiteramos, a partir das palavras de Luna (2005, p. 197) que "[A Poética é] a principal fonte de onde jorram conceitos e ideias para o estudo da arte trágica [da arte literária] e do drama em geral". Para quaisquer considerações teóricas acerca das personagens e sua importância tomaremos como base os textos de Ubersfeld (2010) e Brait (2017).

\section{Ovídio e William Shakespeare: interseções trágicas à luz de Aristóteles e Sêneca}

A primeira leitura que fizemos do mito ovidiano sobre a história trágica vivenciada por Píramo e Tisbe nos remeteu, imediatamente, à tragédia shakespeariana Romeu e Julieta. Muito provavelmente isso ocorreu devido às semelhanças entre os textos, uma vez que elas apresentam uma correspondência de ações que levam a um desfecho trágico em ambas as obras. Vamos, portanto, mostrar como uma e outra obra se constrói e os pontos de interseção entre elas.

Em uma obra literária, a personagem, de acordo com Ubersfeld (2010, p. 72), e concordamos com ela, é o "elemento decisivo da verticalidade do texto", ou seja, é por meio dela que adentramos a obra literária. Uma vez que ela ocupa um "lugar poético", funciona também como mediadora. A concepção de personagem para Aristóteles, ao que ele se refere por 'caráter', corrobora com Ubersfeld no que concerne a sua importância para o texto. Uma diferença reside, por exemplo, no ponto em que para o filósofo grego a trama dos fatos (mythos) e a ação têm maior destaque que os caracteres, posto que "não agem as personagens para imitar caracteres, mas assumem caracteres para efetuar certas ações" (Arist., Po. 1450a 20). As ações efetuadas pelas personagens tanto na tragédia shakespeariana como no mito ovidiano movem a trama até seu doi http://dx.doi.org/10.35572/rlr.v10i3.2141 


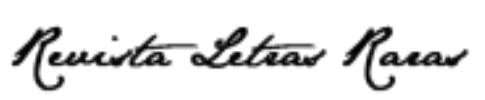

ISSN: 2317-2347 - v. 10, n. 3 (2021)

Todo o conteúdo da RLR está licenciado sob Creative Commons Atribuição 4.0 Internacional

desenlace trágico, consequência de suas escolhas imprudentes, dado que as personagens agem movidas pelo affectus senequiano, conforme perceberemos adiante.

Em seu estudo A Personagem, Brait (2017) discorre sobre diversos aspectos e distintas concepções históricas do que se entendia como personagem até a compreensão contemporânea desta. Ao apresentar considerações sobre a Ars Poetica, do poeta latino Horácio, a pesquisadora acentua os pontos de encontro com a Ars Poetica aristotélica, especialmente no que diz respeito à função pedagógica da poesia - entenda-se por poesia a arte literária como um todo - e a compreensão de que as personagens possuem uma faculdade moral que se revela a partir de suas ações.

No que tange ao aspecto moral das personagens, podemos estabelecer uma relação com a filosofia estoico-senequiana, posto que, não estando mais à mercê da vontade divina, podem tomar as próprias decisões, isto é, realizar escolhas morais das quais assumem as consequências. $A$ possibilidade de agir conforme sua vontade (uoluntas) confere ao personagem a alternativa de desenvolver-se em direção à virtude, condição necessária para que o indivíduo alcance a felicidade plena e tenha uma vida feliz.

A ação trágica, além de ser responsável pela catarse - purificação dos sentimentos, a saber, o terror e a piedade, suscitados pela catástrofe que recai sobre a personagem que é infeliz sem o merecer - possui um caráter pedagógico do qual Sêneca e Horácio compartilham. Sobre 0 caráter pedagógico da literatura, entendemos que, pelos exemplos que podem ser apresentados ao leitor, pode ser didática ao ensinar o homem a alcançar a virtude e a felicidade, vivendo de maneira virtuosa. Relativamente a esta visão presente na literatura estoico-senequiana, Horácio, em sua Ars Poetica, compreende que as noções de moralidade e virtude, por fazerem parte do estatuto dos homens, supõem a imitação, logo a personagem é concebida como modelo a ser imitado. Deste modo, Horácio corrobora para uma tradição que avalia as personagens com base em modelos humanos (BRAIT, 2017).

Os heróis trágicos se configuram, pois, como modelos de ações que não devem ser praticadas, sobretudo porque realizadas sob o efeito do affectus, ou seja, irracionalmente movidos pelo páthos, pelo sofrimento. A partir desse ponto, centraremos a nossa análise estabelecendo uma comparação entre os enredos das duas obras a fim de identificarmos semelhanças quanto à 


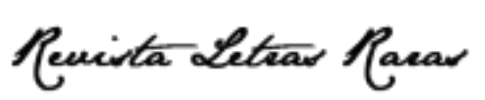

ISSN: 2317-2347 - v. 10, n. 3 (2021)

Todo o conteúdo da RLR está licenciado sob Creative Commons Atribuição 4.0 Internacional

construção da ação trágica, tendo como fundamento de interpretação o estoicismo senequiano, ressaltando os conceitos estoicos, particularmente o affectus, que movem as tramas de Ovídio e de Shakespeare.

Em ambos os enredos, sabemos que algo impede os dois casais de ficarem juntos e que isto se dá por motivos distintos. Em Romeu e Julieta, as famílias Montéquio e Capuleto travam uma luta que se estende por anos e provocam não somente a morte dos dois jovens, mas também de outros jovens das famílias, "vítimas de um ódio cuja origem jamais é identificada" (HELIODORA, 2016, p. 18). Shakespeare coloca em ação dois poderosos sentimentos que estão o tempo inteiro presentes na peça de forma complementar ou oposta um ao outro: o amor e o ódio. Ambos caracterizam-se como sentimentos que despertam no personagem obsessões que podem conduzi-lo até mesmo à irracionalidade, ao ponto de Mercúcio, amigo de Romeu, sugerir que o amor não passa de um sonho ou ilusão, ao que Romeu bendiz a noite, mas reconhece seu medo de que "por ser noite, isto seja só sonho,/ Bom e doce demais para ter substância" (SHAKESPEARE, 2016, 147148).

Tomando a filosofia estoico-senequiana como guia para analisar as duas obras, podemos afirmar que amor e ódio são vícios atrelados à paixão, ou affectus como dizia Sêneca. E as paixões, por sua vez, são as responsáveis por retirar o indivíduo do caminho do bem, da virtude. A paixão é um sentimento externo à alma que precisa do seu consentimento para nela se instalar e, uma vez inserida na alma, toma o lugar da razão, levando o indivíduo a agir por meio de impulsos, tomado completamente pela irracionalidade. Isso significa dizer que paixão e razão não podem coabitar na alma do indivíduo. Se deixar dominar pela paixão significaria que o indivíduo está cada vez mais longe de alcançar a virtude. Os estoicos classificam a paixão como um movimento irracional da alma que se coloca contra a razão e contra a natureza, subdividindo-a em tipos relacionados com a afetividade o que explica, por exemplo, os fenômenos passionais (passio: paixão), a saber: a dor, 0 medo, a concupiscência e o prazer. Diôgenes Laêrtios (D.L. VII) caracteriza a dor como uma "contração irracional da alma", elencando as suas espécies: a compaixão, a inveja, o ciúme, a rivalidade, a aflição, a melancolia, a inquietação, a angústia e o desvario. O medo é definido por ele como uma "expectativa do mal" e se manifesta através do terror, da excitação, da vergonha, da consternação, do pânico, e da inquietação. 


\section{Reuista Letear Racar}

ISSN: $2317-2347$ - v. 10, n. 3 (2021)

Todo o conteúdo da RLR está licenciado sob Creative Commons Atribuição 4.0 Internacional

O mito ovidiano não é claro quanto ao motivo de os pais de Píramo e Tisbe não permitirem a aproximação deles, o que não nos impede de fazer conjecturas. Teriam também estas duas famílias problemas entre si? Pensavam os pais que os filhos seriam demasiado jovens e, por isso, não teriam idade ou maturidade para encontrarem-se? A isso não temos respostas. Os dois jovens tinham, então, uma barreira física real e palpável simbolizando a separação, o desejo de alcançar algo aparentemente impossível. Simbolicamente são separados por uma parede e esta, além de paradigma do inalcançável, mostra-se também ambígua, visto que "a parede comum a ambas as casas abrira pequena fissura,l que se produzira um dia, quando da construção" (OV., Met. IV, 6566). Ao mesmo tempo em que a parede os separa, atuando como objeto palpável que representa a impossibilidade de ficarem juntos, também é a responsável por permitir que se comuniquem através da fissura, ou seja, é ela própria que também aproxima os dois amantes.

Este simbolismo ambíguo da parede e da fissura fica claro pelo próprio discurso de Píramo e Tisbe, que amaldiçoam e agradecem a parede:

'Ciumenta parede, por que te intrometes entre quem se ama?

Que te custava deixar-nos unir nossos corpos completamente?

$\mathrm{Ou}$, se isso fosse demais, abrir-te para nos beijarmos?

Mas não somos mal-agradecidos. Confessamos dever-te o teres proporcionado às nossas palavras passagem para ouvidos amigos.'

(OV., Met. IV, 73-77).

No discurso dos jovens, à parede é atribuído o sentimento humano do ciúme, por se colocar entre 0 amor dos dois. A parede aqui poderia simbolizar também os próprios pais, que por razões desconhecidas, são contrários ao amor dos jovens. A parede representa, no mito ovidiano, o mesmo que os sobrenomes na tragédia shakespeariana: dois elementos relativamente banais. A parede poder-se-ia abrir e dar espaço ao encontro e os nomes (Montéquio e Capuleto) poder-se-iam "serem trocados", como indaga Julieta:

É só seu nome que é meu inimigo:

Mas você é você! Não é Montéquio!

[...] O que há num nome? O que chamamos rosa

Teria o mesmo cheiro com outro nome,

E assim Romeu, chamado de outra coisa

Continuaria sempre a ser perfeito 


\section{Reuista Letear Racar}

ISSN: $2317-2347$ - v. 10, n. 3 (2021)

Todo o conteúdo da RLR está licenciado sob Creative Commons Atribuição 4.0 Internacional

(SHAKESPEARE, 2016, 41-42. 46-47).

Podemos também fazer uma leitura da parede e dos sobrenomes à luz do estoicismo senequiano no que concerne à ira. Entendemos que esta é de fato o grande motivo para a ocorrência das ações trágicas, portanto os elementos que comentamos aqui podem também serem entendidos como símbolos da ira compartilhada entre as duas famílias. Ainda acerca da ira, manifestação da falta de comedimento, responsável por desprover o sujeito das plenas faculdades do lógos, destacou na tragédia shakespeariana os constantes duelos imprudentes travados entre as duas famílias nas ruas de Verona. Verificamos através das atitudes descomedidas das famílias que existe uma relação entre prudência e falta de comedimento. A prudência está diretamente ligada à moderação, princípio necessário na vida do homem, e a falta dela significa descomedimento, ou seja, a causa da destruição do indivíduo. Mercúcio, amigo de Romeu, é constantemente tomado por atitudes impetuosas ao provocar e ser provocado pelos Capuleto, sucedendo quase sempre um duelo, resultado de assuntos banais. A título de exemplo, apresentamos o episódio em que Teobaldo, da casa dos Capuleto, duela com Mercúcio, chegando a matá-lo:

TEOBALDO: [...] Cavalheiros, bom dia: uma palavra.

MERCÚCIO: Só uma palavra com um de nós? Junte mais alguma coisa - é melhor um golpe e uma palavra.

[...] Mas que calma mais vil de desonrosa! Alla stoccata é a palavra de ordem! (saca a espada.) Teobaldo, seu pega-ratos; vamos lá?

TEOBALDO: Ora essa, o que você quer comigo?

MERCÚCIO: Bom Rei dos Gatos, apenas uma de suas vidas

(SHAKESPEARE, 2016, 39-41. 74-79).

O fim desse duelo consiste em uma catástrofe: a morte de Mercúcio e, depois, a de Teobaldo por Romeu. Este vinga o amigo e, ao matar Teobaldo, é exilado de Verona. Podemos observar como a ausência de prudência leva facilmente as personagens ao duelo, que representa, portanto, os efeitos do furor, movendo os sujeitos em direção à vingança. $O$ desejo de vingança aliado à preexistente rivalidade entre as duas casas é a causa da condenação de Romeu e de Julieta, visto que o sujeito dominado pela ira tem, pela vingança, o objetivo principal de causar dor e sofrimento. Sentimentos como a ira e a vingança, por sua vez, não aparecem na narrativa ovidiana, 


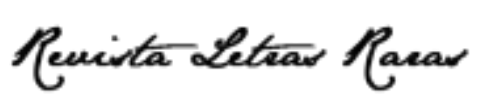

ISSN: 2317-2347 - v. 10, n. 3 (2021)

Todo o conteúdo da RLR está licenciado sob Creative Commons Atribuição 4.0 Internacional

mas a paixão, que leva ao descomedimento, está presente. A partir de agora, veremos como a paixão é retratada no enredo de Píramo e Tisbe.

Píramo e Tisbe vivem uma paixão que cresce gradualmente à medida que é reprimida em termos espaciais. São postos em conflito com o desejo um pelo outro. Dois versos exemplificam isto: "E quanto mais se oculta, mais arde o fogo escondido." (Ov., Met. IV, 62); "Que te custava deixarnos unir nossos corpos completamente?" (Ov., Met. IV, 74). $\mathrm{O}$ autor deixa claro o desejo erótico de um pelo outro, particularmente ao falar em fogo que arde. $\mathrm{O}$ fogo aqui pode representar a energia do amor que sentem e o desejo de consolidar esse amor por meio de seus corpos, pois desejam ardentemente uni-los. Tamanho é este desejo que decidem fugir juntos, assim cometendo uma transgressão, que remete à predominância da irracionalidade - consequência do affectus - sobre a razão: tomam esta atitude movidos pelo desejo e, portanto, não conseguem mensurar as possíveis consequências de seus atos.

Ação semelhante ocorre na tragédia de Shakespeare: Romeu e Julieta, ao se conhecerem, e perceberem ali a paixão que nascera, não somente manifestam em seu discurso a energia do desejo erótico como também decidem se casar em segredo, a fim de não quebrarem o código de honra (fator que não pode ser aplicado ao contexto latino, posto que seria anacrônico). É válido destacar que a relação entre eles não é somente de um amor que não passa pelo crivo do sexo. Muito pelo contrário, a peça está repleta de referências sexuais e eróticas, inclusive não podemos esquecer que Romeu e Julieta são jovens e esperam mais um do outro, como nestas falas, quando estão se despedindo após se encontrarem pela primeira vez: "ROMEU: Mas vais deixar-me assim, insatisfeito?/ JULIETA: E que satisfação posso hoje eu dar?" (SHAKESPEARE, 2016, 132-133). Aqui podemos entender, inclusive considerando o diálogo que o antecede, que Romeu, ao falar de "insatisfação", refere-se também a uma consumação do amor que sentem um pelo outro.

Enquanto Píramo e Tisbe planejam fugir para ficarem juntos, os planos de Romeu e de Julieta são de casamento, pois, especialmente Julieta, tem que lidar com um medo em particular: "Para uma garota da época de Shakespeare, a castidade era uma mercadoria de valor inestimável. Perder sua virtude sem a perspectiva do casamento seria perder-se a si mesma" (BATE; 


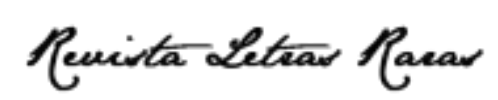

ISSN: 2317-2347 - v. 10, n. 3 (2021)

Todo o conteúdo da RLR está licenciado sob Creative Commons Atribuição 4.0 Internacional

RASMUSSEN, 2007, p. 1676) ${ }^{5}$. A referência ao cuidado e manutenção da castidade está presente também nos conselhos de Frei Lourenço, personagem emblemático que, valendo-se sempre da razão, tenta manter a ordem durante toda a peça. Assim como Ovídio fala de fogo para referir-se ao desejo, o frei também usa o elemento fogo em sua fala sobre o prazer e a castidade:

Violento prazer tem fim violento, E morre no esplendor, qual fogo e pólvora, Consumido num beijo.

[...] Venham comigo pra apressar os votos. Por mim, não ficam sós de modo algum, Até a igreja dos dois fazer um (SHAKESPEARE, 2016, 8-10; 35-37).

Salientamos na fala do frei a relação entre 'prazer' e 'fim violento', na qual podemos identificar o affectus (prazer) que toma a alma dos indivíduos, levando-os a praticar ações desmedidas causando o seu infortúnio.

Ambas as narrativas apresentam prolepses que auxiliam o leitor a entender quais rumos a ação vai tomar. No caso do mito de Ovídio observamos a prolepse, embora não tão clara, no seguinte verso: "[...] combinam encontrar-se junto/ ao sepulcro de Nino e esconder-se na penumbra da árvore." (Ov., Met. IV, 88). A imagem do sepulcro e da penumbra, ao tratar-se do local onde devem se encontrar, evoca a ideia de morte. No texto de Shakespeare, não há necessariamente prolepses, pois o prólogo da peça já anuncia a morte dos protagonistas. No entanto, não fosse 0 prólogo, uma prolepse bastante precisa encontramos na seguinte fala de Romeu pouco antes de conhecer Julieta: "A minha mente teme/ Algo que, ainda preso nas estrelas, Vá começar um dia malfadado/ Com a festa dessa noite, ver vencido/ O termo desta vida miserável" (SHAKESPEARE, 2016, 113-117). As prolepses, para o leitor atento, auxiliam na construção de sentido do texto, uma vez que podemos lê-lo a partir da expectativa do flashforward observado.

Embora o mito escrito por Ovídio não seja uma tragédia, ele se configura a partir de elementos trágicos e assim compreendemos nos baseando nas palavras de Aristóteles acerca do trágico. Observemos o que o estagirita entende por Tragédia:

5"For a girl in Shakespeare's time, chastity was a priceless commodity. To lose her virtue without the prospect of marriage would be to lose herself' (BATE; RASMUSSEN, 2007, p. 1676).

doi http://dx.doi.org/10.35572/rlr.v10i3.2141 


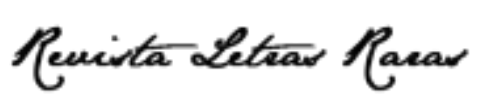

ISSN: 2317-2347 - v. 10, n. 3 (2021)

Todo o conteúdo da RLR está licenciado sob Creative Commons Atribuição 4.0 Internacional

É pois a tragédia imitação de uma ação de caráter elevado, completa e de certa extensão, em linguagem ornamentada e com várias espécies de ornamentos distribuídas pelas diversas partes [do drama], [imitação que se efetua] não por narrativa, mas mediante atores, e que, suscitando o terror e a piedade, tem por efeito a purificação dessas emoções (Arist., Po. 1449b 25).

Os elementos que compõem uma tragédia, de acordo com o filósofo grego, podem ser encontrados em Romeu e Julieta, uma vez que Shakespeare teve acesso aos tragediógrafos latinos, que por sua vez, tinham os gregos como referência. No entanto, podemos encontrar nas palavras de Aristóteles certa flexibilidade que nos permite estender os conceitos à arte literária, não só dramática, posto que em sua Ars Poetica, Aristóteles utilizava também exemplos extraídos de epopeias.

Um elemento caracterizador da tragédia é a catástrofe e ela está presente em ambos os enredos. Tanto em Romeu e Julieta como em Píramo e Tisbe acontece um desencontro, provocado por um erro cuja responsabilidade recai nas próprias personagens. Esses erros não são de responsabilidade divina, isto é, são situações causadas pelo caráter hubrístico das personagens, não é algo predestinado pelos deuses. Nossa afirmação a respeito da não responsabilidade divina e sim na uoluntas (vontade) do herói baseia-se na filosofia estoico-senequiana. Os estoicos acreditam que o lógos não é suscetível a erros, ou seja, para que eles não ocorram o indivíduo precisa seguir a providência (destino). Embora Sêneca assegure que o homem tem o poder de escolher permanecer no vulgo ou buscar a felicidade, entendemos que essa decisão não é de todo livre, pois para que ele seja feliz e alcance a virtude, ele precisa necessariamente aceitar o que o lógos quer. 0 indivíduo pode não querer seguir o lógos mas, escolhendo esse caminho, as consequências são desastrosas, uma vez que ele viverá no erro e nos vícios, distante da verdade e da virtude, vivendo como um joguete da fortuna.

A razão fornece ao indivíduo sabedoria necessária para que ele decida qual caminho seguir; é ela também que aquieta a impulsividade, os desejos e elimina o medo. 0 homem é um ser divino dotado de razão; ele nasce, portanto, bom por natureza, mas torna-se vulnerável aos vícios, pois vive em sociedade cujos indivíduos são doentes da alma. Dessa forma, aqueles não dotados de sapiência podem ser influenciados pelo meio em que vivem e se deixar afetar pelo que é exterior, 


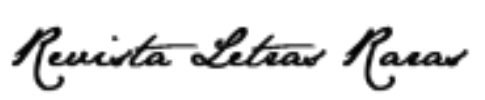

ISSN: 2317-2347 - v. 10, n. 3 (2021)

Todo o conteúdo da RLR está licenciado sob Creative Commons Atribuição 4.0 Internacional

sobretudo se estiverem sempre em contato com pessoas que vivem longe da virtude, ou seja, dominadas pelos vícios. Sêneca nos ensina que os vícios não são naturais, mas gerados a partir do convívio do indivíduo na sociedade (Sen., Ep. 94, 54-56), uma vez que ele se deixa afetar pelos prazeres externos. Na natureza, existe o que é benéfico (a sabedoria e a virtude) e o que é danoso (a ignorância e o vício). Diretamente ligadas a isso estão as ações que podem ser corretas, quando seguem o lógos, e as ações não corretas, que são as movidas pelos vícios e pela paixão. Para os estoicos, viver significa sentir; e Brun (1986, p. 36) nos auxilia a compreender o que isso significa: "sentir é ter os sentidos e a alma modificados pelo que é exterior; esta modificação pode estar em harmonia, e neste caso estamos na verdade, ou pode estar em desacordo, e nesse caso estamos no erro e na paixão."

Shakespeare, influenciado pelo drama senequiano permeado pelos ideais estoicos, faz prevalecer, em todas as suas tragédias, a vontade do herói. Percebemos, nos seus textos, que 0 próprio homem é o responsável pelas suas ações. Esse mesmo aspecto reconhecemos no mito ovidiano de Píramo e Tisbe, que surge de um contexto, no qual ainda que exista uma forte influência dos deuses em diversos aspectos e situações, é o caráter o responsável pela catástrofe. 0 que move o trágico é, pois, a paixão, o medo de ter perdido a amada faz com que os heróis tirem sua própria vida.

O termo paixão pode ser compreendido, de acordo com Cícero, ao lançar mão da definição utilizada por Zenão, como aquilo que perturba a alma, contrária à razão e à natureza (Cic., Tusc. IV, 11). Como já afirmamos anteriormente, a paixão (affectus) é um sentir externo à alma e o indivíduo não deve permitir que ele surja, porque, uma vez que ele se faz presente, não se pode controlá-lo pelo fato de que ele não obedece à razão. A não obediência à razão ocorre, pois a causa do affectus é externa à alma; por isso, Sêneca, criticando os peripatéticos, afirma que a paixão

por pequena que seja, recusa-se à obediência aos ditames da razão. Tal como nenhum animal é capaz de obedecer à razão [...] assim também as paixões não acatam nem escutam avisos, por mais reduzidas que sejam [...] Aliás, com 0 auxílio da razão, as paixões nem sequer despertam; e se despertam contrariando a razão, persistirão nas mesmas condições. É bem mais fácil impedir que elas se originem do que dominar depois os seus ardores (Sen., Ep. 85, 8-9). 


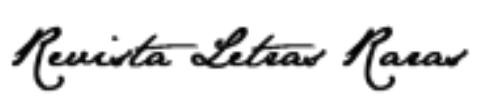

ISSN: 2317-2347 - v. 10, n. 3 (2021)

Todo o conteúdo da RLR está licenciado sob Creative Commons Atribuição 4.0 Internacional

Cícero (Tusc. IV, 16) elenca algumas subdivisões no que diz respeito às perturbações: no domínio do medo estão a preguiça, a vergonha, o terror, o temor, o pavor, o espanto, a conturbação e o receio; ligadas ao prazer estão a malevolência alegre com o mal alheio, o deleite, e a vaidade; e no âmbito da sensualidade estão a ira, a fúria, o ódio, a inimizade, a discórdia, a indigência, e o desejo.

As primeiras imagens que despertam temor em Píramo são os "vestígios da fera" (Ov., Met. IV, 105) que, imediatamente, o empalidecem por completo. Ou seja, nesse momento, ocorre o que Sêneca chama de prelúdio da paixão: a alma de Píramo se deixa enganar pelas pegadas da fera e, assim, se abre para que o temor se instale nela. A segunda imagem, a da veste manchada de sangue (Ov., Met. IV, 107), faz com que a alma de Píramo, já dominada pela paixão, tome uma atitude desastrosa e trágica. As perturbações elencadas por Cícero se encontram manifestas na alma de Píramo: temor, espanto e furor. Dominado por esses sentimentos que trazem consigo um sofrimento arrebatador, o herói anuncia: "uma única noite vai perder dois amantes" (Ov., Met. IV, 108).

Romeu também é tomado pelo temor, mas antes mesmo de encontrar Julieta "como morta" na tumba. Ainda em seu exílio, Baltasar, um mensageiro, consegue chegar primeiro que 0 mensageiro do Frei Lourenço, comunicando a Romeu a "morte" de Julieta. A partir desse instante, Romeu assume uma atitude que, embora já tomada pela irracionalidade, é premeditada quanto aos planos trágicos que pretende cumprir. Podemos identificar que a notícia trazida por Baltasar desperta o temor em Romeu a partir das próprias falas do mensageiro: "Meu senhor, eu peço, seja paciente;/ A sua louca palidez sugere/ Algum desastre" (SHAKESPEARE, 2016, 29-30). Romeu, desequilibrado pelo temor, opta pela morte quando planeja e compra o veneno de um boticário, entendendo a morte como algo bem-vindo, uma vez que não teria mais a seu lado a correspondência de Julieta à sua paixão: "Eu não comprei veneno, comprei cura;/ E bebo ao meu amor, na sepultura" (SHAKESPEARE, 2016, 90-91).

De acordo com Sêneca, a causa da ira encontra-se na injúria e ela surge devido a um julgamento errôneo da imagem percebida pela alma. Como consequência precisa obrigatoriamente ser extravasada, tendo como único objetivo a vingança. Podemos compreender melhor a definição de ira a partir do que Sêneca expõe no diálogo Sobre a Ira: 


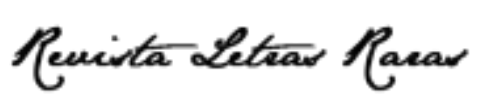

ISSN: 2317-2347 - v. 10, n. 3 (2021)

Todo o conteúdo da RLR está licenciado sob Creative Commons Atribuição 4.0 Internacional

é plena de excitação e ímpeto, enfurecida por uma ânsia desumana de dor, combates, sangue, suplícios. Indiferente a si, desde que seja nociva a outro, ela se arroja a seus próprios dardos e é ávida por uma vingança que há de arrastar consigo o vingador [...] ela é igualmente desenfreada, alheia ao decoro, esquecida de laços afetivos, persistente e aferrada ao que começou, fechada à razão e aos conselhos, incitada por motivos vãos, inábil em discernir o justo e 0 verdadeiro, muito similar a algo que desaba e se espedaça por cima daquilo que esmagou. (Sen., Ir. I 1, 1-2).

O filósofo se utiliza de dois adjetivos importantes para qualificar a ira: concitatus (excitação, arrebatação) e impetus (ímpeto, impulso), ambos derivados de verbos que indicam movimento violento em direção a algo ou alguém, um lançar-se $a^{6}$. 0 affectus ocorre através de estímulo externo à alma, desencadeando o sentimento de furor, afetando aquele que se deixa dominar pela ira fazendo-o lançar-se violentamente, movido pela vingança destrutiva, em direção a algo ou a alguém, com o objetivo principal de causar dor e sofrimento.

A culpa é um dos sentimentos que afetam Píramo, é um dos motivos que causam nele dor e despertam a fúria nefasta:

É minha culpa. Fui eu, infeliz, quem te perdeu, eu que te disse para vires de noite para lugares tão cheios de medo e não me antecipei a vir. Despedaçai meu corpo e consumi minhas entranhas criminosas com feras dentadas, ó leões todos que viveis nestas serras!

(Ov., Met. IV, 110-114)

Sua alma tomada pela paixão, pela dor da perda, ou seja, totalmente ausente de razão, permite que o movimento ou impulso devastador ocorra. Sêneca nos ensina que "embora [a ira] seja inimiga da razão, no entanto, em parte alguma ela nasce a não ser onde a razão tem lugar." (Sen., Ir. I 3, 4). A ira, portanto, é um impulso que precisa ser extravasado, arrebatando consigo a razão. E, como impulso, necessita obrigatoriamente do consentimento da alma. No processo de eclosão da ira, há um sentimento inicial que independe da vontade da alma, pois não é ainda a paixão, mas um

\footnotetext{
${ }^{6}$ Respectivamente, concito, -as, -are, -avi, -atum - frequentativo de concieo, concio(GAFFIOT, 2000, pp. 376-377); ou como composto de cieo, -es, -itum (ERNOUT; MEILLET, 2001, pp. 119-120); e impeto, -is, -ěre, -, -itum(in, peto) (GAFFIOT, 2000, p. 788); ou como composto de peto, -is, -ĕre, -iui(ii), -itum (ERNOUT; MEILLET, 2001, p. 503). doi http://dx.doi.org/10.35572/rlr.v10i3.2141
} 


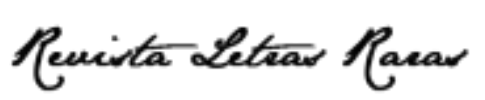

ISSN: 2317-2347 - v. 10, n. 3 (2021)

Todo o conteúdo da RLR está licenciado sob Creative Commons Atribuição 4.0 Internacional

prelúdio. Em seguida, o movimento depende da vontade da alma, pois já a afeta de alguma forma uma vez que ela se sente ofendida - nesse momento de fraqueza da alma a paixão se instala, toma todo o ser, e começa a sua empreitada em busca de vingança. Por fim, o ser todo tomado em affectus, em ira, não consegue mais livrar-se dela. No ser tomado de ira, ocorre uma desordem mental, impedindo-o de comandar suas próprias ações, manifestando uma explosão irascível de furor intensa, mas passageira. O espaço de tempo da ira é curto, mas devastador; e a consciência da destruição causada pelo furor ocorre depois de passado o instante de furor. Nesse momento, o homem se assemelha ao animal irracional ${ }^{7}$, uma vez que se encontra desprovido de sua capacidade racional, ele está todo entregue ao affectus. Além disso, sua alma transformou-se em paixão e perdeu sua saúde primitiva.

Píramo, ao ver o véu de Tisbe manchado de sangue, se desespera. Ora, ele poderia ter pensado em uma alternativa, ou esperado um pouco mais, ou ainda gritado por ela, mas a característica profundamente humana do desespero ante uma possível perda, e já completamente tomado pelo affectus, mostra-se essencial na construção da ação desenvolvida por Ovídio. 0 mesmo poder-se-ia argumentar acerca de Romeu, que tivesse esperado alguns segundos a mais, teria evitado a catástrofe.

O herói do mito ovidiano, tomado pela dor de imaginar ter perdido a sua amada,

[...] recolhe o véu de Tisbe

e leva-o consigo para debaixo da penumbra da árvore combinada.

$E$, enquanto chorava e beijava o véu de si conhecido, diz:

'Recebe agora também o hausto do meu sangue?!'

E cravou nas entranhas o ferro que trazia cingido.

(Ov., Met. IV, 115-119)

Tisbe, ao reconhecer o amado ferido e moribundo no chão, também permite que a paixão afete sua alma. Ela, da mesma forma que ele outrora, se deixa levar pela dor e pelo sofrimento que fazem eclodir a fúria que, inicialmente, faz com que ela fira seus braços (Ov., Met. IV, 139) e, em

\footnotetext{
${ }^{7}$ Sêneca elenca inúmeros sinais físicos, ao discorrer sobre o irado (Sen., Ir. I 1, 4); e, para exemplificar a proeminência da ira, o filósofo se utiliza da agressividade dos animais irracionais, assegurando que "nenhum animal é tão horrendo e tão perigoso por natureza que nele não fique aparente, logo que a ira o tenha invadido, o acréscimo de renovada ferocidade." (Sen., Ir. I 1, 6-7). Faz-se necessário ressaltar que os animais desconhecem a ira, manifestam apenas um sentimento similar; eles foram privados não só das virtudes, mas também dos vícios.
} 


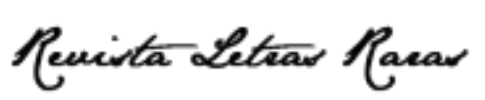

ISSN: 2317-2347 - v. 10, n. 3 (2021)

Todo o conteúdo da RLR está licenciado sob Creative Commons Atribuição 4.0 Internacional

seguida, arranque seus cabelos (Ov., Met. IV, 140). Agindo por impulso motivada pela paixão, ela grita, sofre e decide: "Eu também tenho mão forte, ao menos para isto! / Também eu tenho amor! Há de este dá-me forças para me ferir!" (Ov., Met., IV, 150-151). Após um breve solilóquio doloroso, Tisbe, "ajustando a espada abaixo do peito, / lançou-se sobre o ferro, tépido ainda da outra morte." (Ov., Met., IV, 162-163).

Píramo e Romeu, assim como Tisbe e Julieta, se aproximam nesse sentido, pois todos se deixaram dominar pela paixão e suas ações demonstram a irracionalidade causada pela ausência da razão em suas almas.

Uma vez que falamos em catástrofes, Aristóteles a entende como "uma ação perniciosa e dolorosa, como o são as mortes em cena, as dores veementes, os ferimentos e mais casos semelhantes" (Arist., Po. 1452b 10). Imputamos difícil de refutar que a morte de Romeu e de Julieta, bem como a de Píramo e Tisbe, são grandes catástrofes. Ambas as mortes, cada uma com suas nuances, exploram o páthos do espectador e do leitor, posto que se trata da morte das personagens por motivos fúteis e banais de desencontros, além das personagens terem bondade em si, ou seja, estarem mais propensas para o bem do que para o mal (Arist., Po. 1454a 20).

A diferença nas catástrofes das duas obras em questão reside, por exemplo, na explicitação da violência. Romeu toma o veneno e, antes de morrer, diz: "Honesto boticário, rápida é a droga. $E$ assim, com um beijo, eu morro" (SHAKESPEARE, 2016,119-120); Julieta por sua vez diz: "Ah, lâmina feliz, enferruja em meio peito pra que eu morra!" (SHAKESPEARE, 2016, 174-175). Embora Julieta se apunhale em cena, ainda assim estas ações catastróficas não se assemelham às descritas no texto de Ovídio.

Ovídio deixa muito mais claro o aspecto violento da morte dos dois amantes. Píramo crava um ferro em suas entranhas "e arranca-o, em seguida, da ferida ainda quente,/ Ao ficar estendido de costas no chão, o sangue repuxa com força..." (Ov., Met., IV, 120-121). Ao descrever a morte de Tisbe, o realismo que a figura pode construir na mente do leitor não a torna menos crua:

\footnotetext{
Mas, logo que reconheceu o seu amor, fere com sonoros golpes seus braços, que não o mereciam. $E$, enquanto arranca o cabelo e abraça o corpo amado, banha de lágrimas as feridas e ao sangue mistura o choro
} 


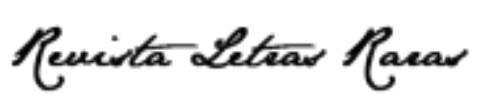

ISSN: 2317-2347 - v. 10, n. 3 (2021)

Todo o conteúdo da RLR está licenciado sob Creative Commons Atribuição 4.0 Internacional

(Ov., Met., IV, 137-141).

Entendemos que, diferentemente do texto de Shakespeare, pertencente à dramática, o de Ovídio, épico, não foi escrito para ser encenado. Ainda que Shakespeare investisse em cenas violentas como duelos e assassinatos em suas tragédias, os recursos dos quais as playhouses ${ }^{8}$ dispunham, apesar de avançados para a época, não seriam suficientes para a performance de uma riqueza maior de detalhes a mais do que era cabido às convenções e às condições. Dessa forma, acreditamos que este é um dos motivos que possibilita a Ovídio a descrição de uma morte mais violenta e grotesca do que seria possível a sua encenação no palco.

Ambas as mortes suscitam o terror e a piedade. Em Shakespeare, o fato de os protagonistas serem tão jovens e recém-casados, e morrerem por causa de uma luta de família da qual eles nem sequer talvez entendessem a essência. Não somente a ação das catástrofes em si, igualmente o discurso das personagens mostra-se essencial no que concerne ao suscitar o terror e a piedade: "[esta] tem lugar a respeito do que é infeliz sem o merecer, e o terror, a respeito do nosso semelhante desditoso" (Arist., Po. 1453a 5). Tanto Julieta quanto Romeu, ao contemplar um o corpo desfalecido do outro são capazes de provocar profunda piedade da plateia ou do leitor, bem como Tisbe ao encontrar seu amado padecendo. Podemos destacar, além da própria morte dos dois, a fala de Tisbe quando vê Píramo perecendo: "Píramo, que desgraça te roubou a mim?/ Responde, Píramo! É a tua Tisbe, meu querido, / quem te chama! Ouve e levanta a cabeça desfalecida" (Ov., Met. IV, 142-144). As próprias falas de Tisbe diante do corpo de Píramo potencializam o páthos. Faz-se necessário mencionar um aspecto, que não está presente em Romeu e Julieta, que é o fato de Píramo ainda não estar completamente morto quando Tisbe o encontra, ou seja, ela vê e vive até no último momento o impossível, o inalcançável. Mediante os ferimentos que ele impunha a si mesmo, nada mais o salvaria.

\footnotetext{
8 "Para entender a vida teatral original de Shakespeare, devemos esquecer os teatros internos das épocas posteriores, com seu arco de proscênio e cortinas que seriam abertas no início e fechadas ao fim de cada ato. Shakespeare, por outro lado, escreveu para um palco de plataforma vazia com uma plateia em pé reunida em torno dele em um pátio em plena luz do dia" (BATE; RASMUSSEN, 2007, p. 23-34). "To understand Shakespeare's original theatrical life, we have to forget about the indoor theatre of later times, with its proscenium arch and curtain that would be opened at the beginning and closed at the end of each act. [...] Shakespeare, by contrast, wrote for a bare platform stage with a standing audience gathered around it in a courtyard in full daylight."
}

doi) http://dx.doi.org/10.35572/rlr.v10i3.2141 


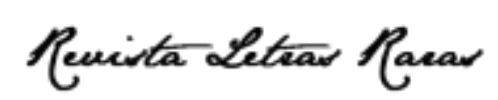

ISSN: 2317-2347 - v. 10, n. 3 (2021)

Todo o conteúdo da RLR está licenciado sob Creative Commons Atribuição 4.0 Internacional

Podemos afirmar que outra característica que se não une, mas aproxima consideravelmente as duas histórias, é o sacrifício como necessário para a instauração de uma nova situação. Na Tragédia de Shakespeare, não só a morte dos protagonistas, mas de outros jovens das duas famílias rivais, são lamentadas pelo príncipe de Verona e, são estas mortes os sacrifícios puros para pôr fim à luta dos Montéquio e Capuleto:

MONTÉQUIO: Farei por ela estátua de ouro puro.

Enquanto esta cidade for Verona

Não haverá imagem com o valor

Da de Julieta, tão fiel no amor.

CAPULETO: Romeu, em ouro, estará ao seu lado,

Que o ódio foi também sacrificado.

(SHAKESPEARE, 2016, 310-315).

O mesmo acontece com Píramo e Tisbe, mas no que diz respeito a eles, podemos dizer que seu sacrifício instaurou a nova situação do seu amor, já que em vida não puderam ficar juntos, pelo menos na morte isto Ihes fora garantido. Quanto às suas famílias não sabemos se eram rivais, mas concordaram em não separar Píramo de Tisbe: "Seus votos chegaram aos deuses e chegaram aos pais,/ pois nos frutos, quando estão maduros, é negra a cor,/ e o que resta das piras repousa numa urna só" (Ov., Met. IV, 164-166).

\section{Conclusão}

Os temas que podemos refletir no mito de Ovídio aparecem também no texto de Shakespeare à medida que as paixões intensas convergem para transformações dramáticas e a energia do amor que emana dos corações jovens se esvai brutalmente. Nas palavras de Bate e Rasmussen (2017, p. 165), "Píramo e Tisbe encontram-se em uma tumba antiga fora da cidade. Eles caem por terra na morte, mas o amor deles é simbolicamente lembrado no amadurecimento da amora cor de sangue" ${ }^{\prime \prime}$. A relação com a terra pode também ser estabelecida em Romeu e Julieta

\footnotetext{
9"Pyramus and Thisbe meet by an ancient tomb outside the city. They fall to earth in death, but their love is symbolically remembered in the ripening of the blood-dark mulberry".

doi http://dx.doi.org/10.35572/rlr.v10i3.2141
} 


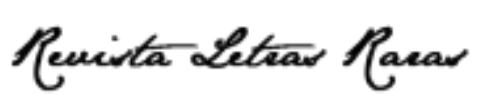

ISSN: 2317-2347 - v. 10, n. 3 (2021)

Todo o conteúdo da RLR está licenciado sob Creative Commons Atribuição 4.0 Internacional

quando o Frei Lourenço afirma "A terra-mãe de tudo é também cova:/ O que ela enterra o seu ventre renova" (SHAKESPEARE, 2016, 5-6).

A ideia de renovação e esperança permeia os dois desfechos trágicos, em uma perene lembrança dos jovens por meio das amoras maduras e em outro a renovação que simboliza a instauração de uma nova realidade, uma vez que os Montéquio e os Capuleto apenas se reconciliam por causa do sacrifício operado por Romeu e Julieta.

É válido destacarmos aqui, a partir da filosofia estoico-senequiana, como a paixão, o affectus, é responsável por mover as duas tramas. Tanto a ira como o amor conflituam a todo instante com o lógos, ou seja, os impulsos da alma tomada pelo affectus traduzem-se nos enredos a partir de ações que engendram as consequências trágicas, a saber, a ira inexplicável instaurada entre as duas famílias rivais de Verona, e o amor desmedido entre Romeu e Julieta e entre Píramo e Tisbe.

O texto de Ovídio e o de Shakespeare podem ser vistos, a partir da filosofia estoica, como instrumentos que podem conferir ao leitor/espectador uma experiência didática a partir da vivência do páthos provocada pelas ações das personagens. Os desenlaces catastróficos, portanto, trágicos, servem como aprendizado às suas distintas recepções. Apesar de não ser possível aferirmos o quão transformadora é a recepção de uma obra literária por cada leitor, nem é esse o nosso intuito, acreditamos no seu potencial didático no que diz respeito à reflexão sobre a importância da faculdade da razão e à educação dos sentimentos suscitados pela ação trágica.

A leitura das duas obras pode proporcionar reflexões acerca do comedimento e da prudência, reflexões estas que pelo estoicismo senequiano devem ser aplicadas à prática e não apenas ficar no campo da teoria. Percebemos como a ira das duas famílias incitava duelos gratuitos que resultaram na morte de jovens. Inclusive, identificamos também este aspecto da peça de Shakespeare: a quantidade de jovens que morrem por causa da ira de outrem, que facilmente lhes toma a alma, tornando-os corresponsáveis com a rivalidade. Em Píramo e Tisbe, a paixão, que lhes privara de todo comedimento e prudência é responsável por suas mortes. Por conseguinte, a falta de equilíbrio das personagens é algo didático, pelo qual pode-se aprender a moderação e o equilíbrio.

É necessária a morte das personagens para que uma transformação ocorra, afirmação essa que pode ser verificada pelo fato de as duas famílias terem aprendido com as catástrofes que 


\section{Remista Letiar Racar}

ISSN: 2317-2347 - v. 10, n. 3 (2021)

Todo o conteúdo da RLR está licenciado sob Creative Commons Atribuição 4.0 Internacional

resultaram de sua ira. De modo particular, gostaríamos de chamar atenção para a nova realidade instaurada pela morte de Píramo e Tisbe. A morte dos dois, que ocorre debaixo de uma amoreira, apresenta características simbólicas contraditórias, posto que a árvore em si representa a vida ou a vitalidade. No entanto, mesmo após a morte deles, não podemos constatar a ausência de vida, uma vez que o sangue de Píramo e Tisbe regam a árvore e pintam de cor púrpura as amoras, imprimindo na natureza a vitalidade de um amor outrora intenso.

\section{CRediT}

Reconhecimentos: Não é aplicável.

Financiamento: Não é aplicável.

Conflitos de interesse: Os autores certificam que não têm interesse comercial ou associativo que represente um conflito de interesses em relação ao manuscrito.

Aprovação ética: Não é aplicável.

Contribuições dos autores:

Conceitualização, Investigação, Administração do projeto, Supervisão, Validação, Escrita - rascunho original, Escrita - revisão e edição: PINTO, Jorge Alves; DE CALDAS, Viviane Moraes.

\section{Referências}

ARISTÓTELES. Poética. Tradução de Eudoro de Souza. São Paulo: Ars Poética, 1993.

BATE, Jonathan \& RASMUSSEN, Eric. William Shakespeare: Complete Works. The Royal Shakespeare Company: Macmillan, 2007.

BRAIT, Beth. A Personagem. São Paulo: Contexto, 2017.

BRUN, Jean. O estoicismo. São Paulo: Edições 70, 1986.

CICERO. Discussões tusculanas. Tradução Bruno FregniBassetto. Uberlândia: EDUFU, 2014.

CLOSEL, Régis Augustus Bars. Revisando a História da Influência de Sêneca em Shakespeare. Letrônica, v. 4, n. 1, p. 105-121, 2011.

DIÔGENES LAÊRTIOS. Vidas e doutrinas dos filósofos ilustres. Tradução, introdução e notas de Mário da Gama Kury. 2. ed., reimpressão. Brasília: EditoraUniversidade de Brasília, 2008.

ERNOUT, Alfred; MEILLET, Alfred. DictionnaireÉtymologique de la Langue Latine: Histoire des mots. Retirage de la 4e. édition, nouveau format. Paris: Klincksick, 2001.

GAFFIOT, F. Le Grand Gaffiot: Dictionnaire Latin Français. 30éme éd. Paris: Hachette, 2000. 


\section{Revista Letear Racar}

ISSN: 2317-2347 - v. 10, n. 3 (2021)

Todo o conteúdo da RLR está licenciado sob Creative Commons Atribuição 4.0 Internacional

HELIODORA, Bárbara. Introdução. In: SHAKESPEARE, WILLIAM. Romeu e Julieta. Tradução e introdução de Bárbara Heliodora. Rio de Janeiro: Nova Fronteira, 2016.

LOHNER, José Eduardo dos Santos; FREITAS, Renata Cazarini de. Reconhecer e traduzir traços de Sêneca em Shakespeare. Cadernos de Tradução, v. 1, n. 33, p. 287-289, 2014.

LUCAS, Frank Laurence. Seneca andElizabethantragedy. UniversityMicrofilms, 1922.

LUNA, Sandra. Arqueologia da Ação Trágica: o legado grego. - João Pessoa: Idéia, 2005. Idéia, 2008.

OVÍDIO. Metamorfoses. Tradução, introdução e notas: Domingo Lucas Dias. São Paulo: Editora 34, 2017.

SÊNECA. Cartas a Lucílio. Tradução J. A. Segurado e Campos. 5. ed. Lisboa: Fundação Calouste Gulbenkian, 2014.

SÊNECA. Sobre a Ira. Sobre a Tranquilidade da Alma. Tradução, introdução e notas de José Eduardo S. Lohner. São Paulo: PenguinClassics Companhia das Letras, 2014.

SHAKESPEARE, WILLIAM. Romeu e Julieta. Tradução e introdução de Bárbara Heliodora. Rio de Janeiro: Nova Fronteira, 2016.

UBERSFELD, Anne. Para ler o teatro. Tradução José Simões (coord.). São Paulo: Perspectiva, 2010. 